\title{
Neoliberalism, trade imbalances, and economic policy in the Eurozone crisis
}

Neoliberalismo, desequilíbrios comerciais e política econômica na crise da Zona do Euro

\begin{abstract}
This paper analyzes the causes of the Eurozone crisis. In doing so, it carefully surveys authors from different economic schools of thought. The paper discusses competing explanations for European current account imbalances. Remarkably, opposing views on the relative importance of cost developments and demand developments in explaining current account imbalances can be found in both heterodox and orthodox economics. Regarding the assessment of fiscal and monetary policy there is a clearer polarisation, with heterodox analysis regarding austerity as unhelpful and most of orthodox economics endorsing it. We advocate a post-Keynesian view, which holds that current account imbalances are not a fundamental cause of the sovereign debt crisis. Rather, the economic policy architecture of the Eurozone, which aims at restricting the role of fiscal and monetary policy, is the key to understanding the crisis in Europe.
\end{abstract}

\section{Keywords}

Euro crisis; neoliberalism; European economic policy; financial crisis; sovereign debt crisis; current account balance.

JEL Codes B00; E00; E5; E63; F53; G01.

\author{
Engelbert Stockhammer \\ Kingston University \\ Collin Constantine \\ Kingston University \\ Severin Reissl \\ Kingston University
}

\section{Resumo}

$O$ artigo analisa as causas da crise da Zona do Euro, revisando de maneira cuidadosa as perspectivas adotadas por autores de diferentes escolas de pensamento. $O$ artigo discute explicações alternativas para os desequilibrios em conta corrente que atingem a Europa. De forma notável, visões opostas acerca da importância relativa de fatores de custo e de demanda na explicação de desequilibrios de conta corrente podem ser encontradas na economia tanto ortodoxa quanto heterodoxa. No que concerne a avaliação de políticas fiscais e monetárias, há uma polarização mais clara: a análise heterodoxa vê a austeridade como contraproducente, ao passo que a economia ortodoxa subscreve medidas dessa natureza. Defendemos uma posição pós-keynesiana, que não enxerga os desequilíbrios em conta corrente como uma causa fundamental da crise da divida soberana. Pelo contrário, a arquitetura de política econômica da Zona do Euro, que pretende restringir o papel das políticas fiscal e monetária, oferece a chave para compreensão da crise europeia.

\section{Palavras-chave}

Crise do Euro; neoliberalismo; política econômica europeia; crise financeira; crise da divida soberana; balança de transações correntes.

Códigos JEL BO0; EO0; E5; E63; F53; G01. 


\section{Introduction}

While the whole world economy was shaken by global financial crisis 2008/09, most countries have seen some form of recovery. However, only in the southern European Euro member states did the crisis escalate into a prolonged depression; and only in these countries did the crisis turn into a sovereign debt crisis. What explains this unique experience of the Eurozone? Baldwin and Giavazzi (eds., 2015), in presenting a 'consensus view' of the Eurozone crisis put large current account imbalances and the associated financial flows at the centre of their explanation. In contrast, we will argue that there is in fact a great variety of opinions both on the causes of these current account imbalances, and also on whether or not they are central to an explanation of the sovereign debt crisis. In our own analysis, we put fiscal and monetary policies that have been shaped by a neoliberal design at the centre of the crisis. This paper, firstly, examines the controversies surrounding European trade imbalances, especially the debates about the extent to which these are caused by differing trends in cost-competitiveness. We provide a survey of different points of view on this issue which have been advanced both by orthodox and heterodox economists and demonstrate the political implications of these arguments. In attempting to draw a tentative conclusion on the debate about unit labour costs and competitiveness, we argue that one common strand running through the thought of most post-Keynesians (PKs) is that trade balances are not the central element in the Eurozone crisis. At the root of this crisis is a build-up of debt, which, in this case, partly reflected growing current account imbalances. However, the crux of the matter is that there was a financial crisis which hit Europe asymmetrically, and it was the neoliberal fiscal and monetary policy regime of the EMU which turned the financial crisis into a sovereign debt crisis. The paper, hence, secondly, offers a discussion of monetary and fiscal policy in the Economic and Monetary Union (EMU) and its evaluation from different theoretical perspectives.

EMU came with an economic policy package that is rule bound and has proven exceptionally dysfunctional during the crisis. This policy design is inspired by ordoliberalism, a variant of neoliberalism, which aims at constraining government intervention. Macro-economically this has an anti-Keynesian logic; counter-cyclical government intervention 
is ultimately regarded as unnecessary. The imposition of rigid rules on monetary and fiscal policy and the exposure of government finances to market pressures is not an accident, but an integral part of the neoliberal project. These constraints have become binding in the crisis, and have prevented national fiscal policies from fighting the recession. In fact, they have imposed austerity policies on those countries most affected by the crisis. In part, this was made possible by the separation of monetary and fiscal policy, which has meant that countries facing a sovereign debt crisis did not have full central bank support, i.e., they did not have a lender of last resort. Only in this context could the financial crisis play out as a sovereign debt crisis in Europe, and it was the accompanying austerity policies that have turned a recession into the protracted depression we observe today.

The paper is structured as follows: section 2 discusses analyses of neoliberalism and shows how post-Keynesian (PK) Economics can contribute to an understanding of its economic impacts. It also establishes that neoliberal economic policies played a key role in setting the stage for the global financial crisis and the European sovereign debt crisis. Section 3 outlines and evaluates differing explanations of the current account imbalances which characterized the period prior to the crisis and discusses their political implications. Section 4 evaluates the EMU fiscal and monetary policy regime. Based on these discussions, section 5 concludes by way of a proposal for an alternative, PK policy.

\section{Neoliberalism, economic policy and growth models}

Neoliberalism is an attempt to modernise liberal thought and policy after the great wars. Theoretically, it has modified the conceptualisation of markets, states and individuals. Markets are not regarded as arising naturally, but need to be created and maintained by government intervention, which includes both the definition of property rights, but also active competition policies (Foucault, 2008; Mirowski; Plehwe, 2009). The role of the state is thus a surprisingly active one, but the state is also subjected to market-like competition mechanisms. Politically neoliberalism encompasses a variety of projects that have been shaped by the specific historical constellations and power relations (Harvey, 2005; 
Fourcade-Gourinchas; Babb, 2002). There has been extensive debate on the nature of neoliberalism, in the course of which globalisation, financialisation and rising inequality have been identified as key features. ${ }^{1}$ While many discussions of neoliberalism and its variegated impact in different countries or regions draw heavily on political science and often proceed at a fairly high level of abstraction, post-Keynesian economics (PKE) can offer a concrete, detailed and structured analysis of the economic impacts of neoliberalism. Financialisation and the effects of income distribution on growth and economic stability have long been central themes in PK research (Hein, 2012; Stockhammer, 2012). Thus, PKE is particularly well-suited to providing economic discussions of neoliberalism. Specifically, we will show that the PK typology of growth models can clarify neoliberal variegation in terms of demand regimes and highlight the contradictory dynamics of neoliberalisation. We also highlight PK analysis of money and finance, which lends itself to a theory of debt-driven growth.

Table 1 provides a simple framework to analyzing the interaction of distribution and growth (see Lavoie; Stockhammer, 2013). It classifies growth regimes along two axes: First, the demand regime can be profitled or wage-led, i.e., the effect of an increase in the profit share - which may, for instance, result from a reduction of the bargaining power of labour - on effective demand can be positive or negative. Second, actual distributional changes can be pro-capital or pro-labour, i.e., they can either be increases in the profit share or in the wage share (for an empirical assessment of the drivers of such changes in functional distribution, see Stockhammer, 2016a) This simple framework allows for a rich analysis that can be used to compare different economic theories as well as different country experiences in specific historic periods. Cell $(1,1)$ depicts a situation in which a falling wage share coincides with a profit-led demand regime. This would give a profit-led growth model, corresponding to the trickle-down economy that many neoliberals of the early 1980s were propagating. Rising inequality is a healthy thing because it comes with growth, which will eventually benefit the poor, at least in absolute terms. This is 'neoliberalism in theory'.

1 On neoliberalism see Foucault (2008), Harvey (2005), Brenner et al. (2010), Duménil and Lévy (2004), Glyn (2006), Dardot and Laval (2013); on income distribution see Atkinson et al. (2011) on top incomes and Stockhammer (2016a) on wage shares. 
Table 1 A typology of distribution and growth regimes

\begin{tabular}{l|l|l|l}
\hline & & \multicolumn{2}{|l}{ Actual distributional changes } \\
\cline { 3 - 4 } & & Pro-capital & Pro-labour \\
\hline $\begin{array}{l}\text { Demand } \\
\text { regime }\end{array}$ & Profit-led & $\begin{array}{l}\text { Virtuous profit-led growth process } \\
\text { ('neoliberalism in theory') }\end{array}$ & $\begin{array}{l}\text { Stagnation or external demand } \\
\text { stimulation } \\
\text { ('Failed social reform') }\end{array}$ \\
\cline { 2 - 4 } & Wage-led & $\begin{array}{l}\text { Stagnation or external demand } \\
\text { stimulation, e.g., via debt-driven } \\
\text { or export-driven growth } \\
\text { ('actually existing neoliberalism') }\end{array}$ & $\begin{array}{l}\text { Virtuous wage-led growth process } \\
\text { ('social Keynesianism') }\end{array}$ \\
\hline
\end{tabular}

Source: adapted from Lavoie and Stockhammer (2013).

Cell $(1,2)$ depicts a rising wage share in a profit-led economy, which will not give rise to a viable growth model, but rather to stagnation. It is this scenario that Margaret Thatcher was alluding to when she said 'there is no alternative': social reform is doomed because it cannot generate growth. By contrast, Cell $(2,2)$ combines a rising wage share with a wage-led demand regime. In this constellation, declining inequality and solid growth are not in conflict. Growth is driven by domestic demand financed out of rising wages while negative effects of wage increases on investment or the trade balance are weak or absent. This cell may be interpreted as a depiction of the growth regimes that existed in many developed countries in the decades following World War II. Finally, Cell $(2,1)$ combines a wage-led demand regime with rising inequality, i.e., a falling wage share. This combination cannot deliver a stable growth model, but creates a downward pressure on demand. However, growth can still occur if there are other stimulants. From a PK view, it is in this cell where 'actually existing neoliberalism' resides. Stockhammer et al. (2009) and Onaran and Galanis (2014) provide evidence that the Euro area overall as well as many individual countries are in a wage-led demand regime. Growth during the neoliberal era has thus not been the result of a profit-led accumulation. Rather, two different growth models have emerged: the Anglo-Saxon and southern European countries developed a debt-driven growth model, which was driven by increasing household debt, strong consumption demand and, in some cases, a residential investment boom. Other countries, especially Germany, adopted an export-driven growth model, where domestic demand is weak and growth contributions mostly arise from net exports. Thus, neoliberalism has relied on financialisation and globalisation as 
means for demand stimulation. Both growth models which emerged from this process allow for growth, but are intrinsically unstable, because they rely on increasing debt to income ratios. It is these rising mountains of debt that erupted in the crisis.

So far our analysis has focused on the role of income distribution and demand formation. PKE also offers a distinct analysis of the monetary sphere and the impact of finance on (real) economic activity (Lavoie, 2014). PKE holds that money is central in capitalist economies because it is held in part as an insurance against (incalculable) uncertainty. It is a financial asset that offers liquidity. As a consequence, in times of financial crisis, the demand for money soars and other financial markets may freeze or collapse. Money is created by commercial banks as a side effect of their lending decisions. The financial system is underwritten by central bank and government debt as the safest financial assets. Debt and money are thus intrinsically linked and national financial markets are founded on state authority and government debt as a key asset, even if this will only become apparent in times of crisis. Banks' lending decisions depend critically on expected profits and on the availability of collateral. The most important form of collateral for lending to the non-financial sector is real estate property (Zhang; Bezemer, 2015); the most important from of collateral for lending to financial institutions is government bonds (Gabor; Ban, 2016). In the PK view, changes in private debt can be a source of endogenous cycles and economic instability both in a downward and an upward direction, in particular in a deregulated financial system (Minsky, 1986; Charles, 2008). Government intervention is seen as vital in attenuating these tendencies. On this basis, PKE offers a macroeconomic framework to analyze financial cycles and debt driven growth models.

To what extent can the growth models in Table 1 be identified in the European context? Hein (2013) provides a systematic classification which identifies peripheral European countries as exhibiting the debt-driven growth model. While the level of household debt has been traditionally low in these countries, the household debt has grown rapidly. Indeed, Table 2 shows that the increase in household debt in the southern European countries was not only above the increase in the northern European countries (with the exception of the Netherlands), but it also exceeded that of the USA and the UK. Stockhammer and Wildauer (2016) provide econometric evidence for the role of debt and property prices in determin- 
ing private consumption and residential investment. The rapid expansion of credit was made possible to a significant extent through European financial integration, with policies aimed at creating a single financial market for Europe (Grahl, 2009). This led to massive capital flows from Germany but also France and the UK to the peripheral European countries which soon fueled an unsustainable property boom.

Table 2 Increase in household debt (in \% GDP), 2000-08

\begin{tabular}{lr|lr|lr}
\hline Northern European Countries & Anglo-Saxon Countries & Southern European Countries \\
\hline Germany & -11.3 & USA & 26 & Ireland & 62.7 \\
\hline Netherlands & 32.8 & United Kingdom & 28.1 & Italy & 18.3 \\
\hline Austria & 7.9 & & Greece & 35.5 \\
\hline France & 15.8 & & Spain & 33.8 \\
\hline & & & Portugal & 27.4 \\
\hline
\end{tabular}

Source: Eurostat, except USA: Flow of Funds.

Note: Ireland 2001-2008.

The rapid increases in private (and, in the case of Greece, public) debt can hence be interpreted as a consequence of neoliberal economic policies involving financial deregulation and increasing inequality. At the same time, neoliberalism also provided the blueprints for the monetary and fiscal policy architecture of the European Monetary Union, which is fundamentally aimed at constraining the ability of both nation states and the European institutions to intervene macroeconomically. The basic structure of this architecture can be summarised as follows: First, fiscal policy is essentially national policy. The EU budget, restricted to $2 \%$ of GDP, is too small and too inflexible to serve a macroeconomic function and cannot provide a counter-cyclical stimulus. Second, national fiscal policies are restricted in the short term as the budget deficit must not exceed 3\% of GDP (except in severe recessions) and they must aim at a balanced budget in the medium term. Third, monetary policy is centralized at the EU level and is targeting inflation, with the independent ECB having set the inflation target close to or below $2 \%$. Fourth, financial markets are liberalized, internally as well as externally. Thus, the EU foregoes instruments of controlling credit growth or allocating credit. Fifth, there was a no bail-out clause, stating that neither other national governments nor the ECB will support individual countries which are facing problems in financing themselves. This meant that 
when the financial crisis erupted, the fiscal and monetary policy regime acted to transform it into a sovereign debt crisis in those economies which were hit hardest.

Table 3 ULC, export prices, demand growth and net exports of Eurozone economies

\begin{tabular}{|c|c|c|c|c|}
\hline $\begin{array}{l}\text { Pre-crisis } \\
(1999-2008)\end{array}$ & $\begin{array}{r}\text { Average annual } \\
\% \text { change in } \\
\text { ULC }\end{array}$ & \begin{tabular}{|r|} 
Average annual \\
change in export \\
price deflator
\end{tabular} & \begin{tabular}{|} 
Average annual \\
$\%$ change in \\
domestic demand \\
at current prices
\end{tabular} & $\begin{array}{r}\text { Average of net- } \\
\text { exports of goods } \\
\& \text { services at } \\
\text { current prices as } \\
\% \text { of GDP } \\
\end{array}$ \\
\hline Euro Area & 1.81 & 1.22 & 4.31 & 1.48 \\
\hline Austria & 1.01 & 1.22 & 3.58 & 2.77 \\
\hline France & 1.82 & 0.7 & 4.41 & 0.36 \\
\hline Germany & 0.21 & 0.41 & 1.94 & 3.88 \\
\hline Netherlands & 2.17 & 1.6 & 4.89 & 7.49 \\
\hline Greece & 3.69 & 2.98 & 7.19 & -10.35 \\
\hline Ireland & 3.45 & 0.82 & 9.64 & 12.51 \\
\hline Italy & 2.66 & 1.88 & 4.08 & 0.36 \\
\hline Portugal & 2.59 & 1.73 & 4.95 & -8.98 \\
\hline Spain & 3.41 & 2.33 & 7.76 & -3.74 \\
\hline $\begin{array}{l}\text { Post-crisis } \\
\text { (2009-2015) }\end{array}$ & $\begin{array}{r}\text { Average annual } \\
\% \text { change in } \\
\text { ULC }\end{array}$ & $\begin{array}{r}\text { Average annual } \\
\text { change in export } \\
\text { price deflator }\end{array}$ & \begin{tabular}{|r|}
$\begin{array}{r}\text { Average annual } \\
\% \text { change in } \\
\text { domestic demand } \\
\text { at current prices }\end{array}$ \\
\end{tabular} & $\begin{array}{r}\text { Average of net- } \\
\text { exports of goods } \\
\& \text { services at } \\
\text { current prices as } \\
\% \text { of GDP }\end{array}$ \\
\hline Euro Area & 1.31 & 0.59 & 0.7 & 2.62 \\
\hline Austria & 2.19 & 0.92 & 2.18 & 3.29 \\
\hline France & 1.47 & 0.27 & 1.12 & -1.81 \\
\hline Germany & 2.14 & 0.68 & 2.4 & 5.96 \\
\hline Netherlands & 1.42 & 0.23 & 0.51 & 9.69 \\
\hline Greece & -1.07 & 0.08 & -5.78 & -5.26 \\
\hline Ireland & -2.67 & 1.38 & -0.13 & 17.05 \\
\hline Italy & 1.51 & 0.8 & -0.46 & 0.78 \\
\hline Portugal & -0.44 & 0.41 & -1.29 & -2.41 \\
\hline Spain & -0.64 & 0.59 & -1.46 & 1.01 \\
\hline
\end{tabular}

Source: AMECO; Eurostat.

Prior to the crisis, and on the back of a uniform monetary policy which appeared to be tailored to the needs of the large core economies rather than 
the peripheral countries, the southern European countries experienced substantially higher (export) price and wage inflation as well as faster growth than the north. As Table 3 shows, the peripheral economies which were engulfed in the Eurozone crisis experienced significantly higher increases in ULC as well as in export prices than the core countries prior to the crisis. In addition, they also experienced higher growth in domestic demand. The price and wage developments in the periphery have frequently been used to explain the substantial current account deficits which emerged in the periphery with the inception of the Euro and which were mirrored by export surpluses in the north (Ireland, which possesses a strong export base, is the exception here. Its current account is driven to a larger extent than those of other countries by factors other than trade in goods and services). However, we shall demonstrate in the next section that there are differing views on the relative importance of price-competitiveness and demand-booms respectively in explaining the trade imbalances, and also on the centrality of trade imbalances to explaining the Euro crisis.

\section{The causes and significance of European trade im- balances: the controversy around labour costs}

The role of price competitiveness, and especially the importance of divergent trends in unit labour costs (ULC) in explaining European trade imbalances, has been a subject of controversy among both heterodox and orthodox economists. While some analysts regard divergence in competitiveness as an important (or, in extreme cases, seemingly the only) determinant for current account imbalances, others have questioned whether price competitiveness, and in particular trends in ULC, can explain any significant part of trade imbalances. This debate cuts across the orthodox/ heterodox divide in that proponents and opponents of the view that ULC are an important factor can be found on both sides. However, even when they agree on the importance (or irrelevance) of ULC, heterodox and orthodox authors often derive very different policy implications. Importantly, one' stance on this issue will have implications both for proposals to resolve the current crisis as well as for one's assessment of the longterm viability of the common currency, making this an interesting debate worthwhile of examination. 
There is a long-standing stream in post-Keynesian, in particular among German-speaking PKs, which regards cost competitiveness as an important driver of external balances. Germany has a long tradition of exportorientation and has long used European currency arrangements to achieve a real under-valuation of its currency (e.g., Thomasberger, 1995). For example, Priewe rejects the interpretation of the Euro crisis as related to government profligacy and instead regards "the key problem [...] in the polarized current account balances, which reflect divergent competitiveness of members" (Priewe, 2011, p.1). Priewe, thus, calls for wage coordination in Europe. Mazier and Petit (2013), though less explicit, also regard cost divergence as the prime reason for current account imbalances and are concerned about the lack of nominal exchange adjustments in a currency union. They discuss fiscal transfers and suggest a proposal that effectively suspends the currency union as possible solutions.

In a series of papers, Stockhammer argues that current account positions depend on competitiveness as well as on relative demand developments. Europe has seen the emergence of two neoliberal growth models, a debt-driven, southern European and Anglo-Saxon model based on growing household debt and an export-driven, northern European model. It is the interaction of these that gave rise to current account imbalances. Stockhammer and Sotiropoulos (2014) estimate a fixed effect model for a panel of Euro members from 1999 to 2011 and find that ULC as well as demand have statistically significant effects on current account balances. Stockhammer $(2011,2016 b)$ argues that imbalances have been due to wage suppression core countries such as Germany exhibit, as well as due to debt-driven growth in peripheral European countries. Samarina and Bezemer (2014) provide evidence that credit growth was to a large extent driven by capital inflows but do not offer a rigorous explanation of current account balances.

However, there is also a strand within the PK literature which challenges the view that ULC is an important determinant of trade balances. Storm and Naastepad, the most prominent representatives of this view argue that the labour-cost argument is based on a narrow view of competition, that is, price competition. Labour costs are only a small part of overall costs, typically accounting for less than a quarter of manufacturing gross output price, and structural factors like the technology content of exports and the trade partners' growth performance play a more important role. Storm 
and Naastepad (2015a) contend that Germany's technological capability is a better explanation for its export performance. Using quarterly data from 1996-2008, they find that relative unit labour costs is not a significant determinant of Germany's import share growth, export growth or trade balance. In a panel of Euro countries from 1995-2008, Storm and Naastepad (2015b) find that imports are insensitive to relative ULC, while exports are sensitive to world income growth but less so to labour costs. They claim (without econometric evidence) that capital flows have more explanatory power for the current account deficits in the Eurozone periphery. Storm and Naastepad (2015b) show that Greece, Italy and Portugal specialize in low tech exports and their markets have grown slowly. They argue that this is where the real problem of competition lies and that changes in labour costs cannot solve this problem.

It is not straightforward to reconcile Storm and Naastepad's findings with econometric evidence that support the role of relative costs, both on the mainstream side (e.g. Arghyrou; Chortareas, 2008; Belke; Dreger, 2011; Berger; Nitsch, 2010) and on the PK side (Hein; Vogel, 2008; Onaran; Galanis, 2014; Stockhammer; Wildauer, 2016). First, there are numerous differences in specifications, control variables, estimation technique and samples. To illustrate, much of the literature uses nominal ULC or real ULC, whereas Storm and Naastepad use relative ULC in their estimations. In addition, the time samples of different studies obviously also differ. Future research is needed to assess the importance of these differences. Secondly, Storm and Naastepad do not question a statistically significant partial effect of overall costs. They merely contend that ULC are of limited practical importance. In McClosekey's and Ziliak's (1995) terminology, their argument is about economic, not statistical significance. However, the magnitudes of their economic results certainly conflict with those derived from theoretically similar models by Onaran and Galanis (2014) and Stockhammer and Sotiropoulos (2014). A theoretical problem with the Storm and Naastepad's argument is that their reasoning regarding the small share of ULC in output prices relates to direct labour costs in each separate line of production, disregarding any indirect labour costs embodied in intermediate inputs. This means that the expected ULC-elasticities of output prices that they derive from this exercise should be biased downward.

Another strand of the heterodox literature focuses narrowly on the aspect of price competitiveness, with the effects of financialisation and 
credit-booms stressed in the work of Stockhammer and other PKs (Onaran; Glannis, 2014; Storm; Naastepad, 2015c) being rather secondary. An influential statement of these views has been produced by Flassbeck and Lapavitsas (2013). The argument is that a currency union with a common inflation target requires that wages in all member countries grow in line with this target. Otherwise, current account imbalances will arise, which will eventually lead to crises, although the mechanism which actually triggers the crisis is left rather vague. In this view, a resolution must come through realignment of ULC. Southern economies substantially overshot the defined wage target at the same time as core economies (especially Germany) undershot it before the crisis, meaning that both must adjust. Marxist explanations of the Euro crisis in general are largely in line with this story, focusing on the role of 'neo-mercantilist' German wage-suppression in a regime of fixed exchange rates (e.g., Bellofiore et al., 2011). In contrast with the PK account, Marxist explanations appear to implicitly assume a profit-led demand regime. A problem with these stories is that even if one accepts the alleged primacy of relative ULC in determining trade balances, the theory lacks an explanation of why economic growth in the deficit countries consistently exceeded that of the surplus countries. In addition, the sole focus of some contributions on relative ULC leads to a less comprehensive explanation of the Euro crisis. Lapavitsas (2015a,b) concludes from this analysis that a breakup of the Eurozone or at least the exit of deficit countries is the best solution to the Euro zone's woes.

A macroeconomically similar argument is made by proponents of the Varieties of Capitalism (VoC) approach. They also regard ULC as the key variable in explaining the Euro crisis, but identify differences in wage bargaining coordination and their ability to restrain wage growth as the key for explaining the crisis (Hall, 2014; Johnston et al., 2013). Northern countries with coordinated wage bargaining systems were able to maintain competitiveness; southern countries with less coordinated wage bargaining systems experienced a loss of competitiveness. There is little role for demand developments and financialisation in this story. Ultimately, it regards a fixed exchange rate system and excessive wage growth in the service sectors in the southern European countries as the root of the crisis. Proponents of this view are similarly skeptical about the viability of the Eurozone.

Similar arguments, yet with very different policy conclusions, have been put forward by some orthodox economists. They have pointed to the loss 
of competitiveness of peripheral countries as an important factor whilst regarding the corresponding gain in competitiveness of core economies as less of a problem. Sinn (2014b; see also Sinn; Valentinyi, 2013) views the loss of competitiveness in peripheral economies as an important cause of the crisis and broadly supports the view that adjustment must mainly come from their side. He holds that this should be achieved through austerity and internal devaluation. Sinn (2014a, p. 11) also believes that any necessary adjustment for the surplus countries can be attained by relying on market forces, since "[a]fter years of extensive and excessive capital exports to the southern countries, investors from the north now have realized their mistake and look more towards investment in the home harbour". The European institutions have frequently expressed similar views (Draghi, 2012; Juncker, 2015b; European Commission, 2011), arguing that along with unsustainable fiscal policies, large losses of competitiveness in the peripheral economies were a root cause of the crisis. This serves as a justification of the current policies aimed at fiscal austerity and internal devaluation and is the underlying rationale for the Euro Plus Pact as well as the Five President's Report (Juncker, 2015a) in which the introduction of 'Competitiveness Authorities' to control wage growth plays a major role. This account also diverts attention from the problematic EMU policy regime as such, which as we shall argue is the key to explaining the crisis and now acts as a drag on recovery.

Some other mainstream economists have, however, taken a different view of the Eurozone crisis. They question both the relevance of divergences in competitiveness in causing the current account imbalances and the usefulness of ULC as a proxy for competitiveness. For instance, Diaz Sanchez and Varoudakis (2013) argue that the current account imbalances cannot satisfactorily be explained through changes in price-competitiveness and provide empirical evidence suggesting that financial integration, leading to demand booms in the periphery was a more important factor. Wyplosz (2013) concurs with this view, arguing that causality runs from excessive demand, caused by financial integration and resulting in current account deficits, to divergences in competitiveness via differences in inflation rates. Gabrisch and Staehr (2014) find that the emergence of current account imbalances preceded the divergences in relative ULC. Wyplosz (2013) also contends that the use of ULC as commonly practiced may be misleading. Firstly, aggregate ULC contain both the unit labourcosts of the 
traded and the non-traded sector, and may understate the competitiveness of the traded sector. Secondly, the comparison with Germany may be misleading since the deficit countries do not directly compete with Germany in most markets and have different trade patterns so that the basis of comparison should differ. Thirdly, the common indexing of ULC which uses the introduction of the Euro as the base year implicitly assumes that exchange rates were in equilibrium when the Euro was adopted. A problem with these mainstream arguments is that while they can explain current account deficits without having to resort to price competitiveness, they do not provide a compelling alternative explanation of the current account surpluses in the core economies. This is in contrast to heterodox views that also stress the role of wages in domestic demand formation. Despite his differing view on the role of ULC, Wyplosz essentially reaches the same policy conclusion as other mainstream authors, namely that excessive demand in the periphery must be curbed, i.e., that austerity is necessary, the only difference being that the element of wage cuts is absent.

Proponents as well as opponents of the hypothesis that current account imbalances have been cost driven can thus be found on both sides of the orthodox-heterodox divide. Our discussion also indicated that this debate carries important political implications. Table 3, therefore, presents an overview of the various approaches discussed above as well as the differing policy conclusions associated with them.

Several observations emerge from our discussion. First, there is a surprising variability between analytical assessments and policy conclusions. For example, austerity in the deficit countries has been advocated by authors who argue that imbalances are cost driven (e.g., European Commission, 2011) as well as by those who suggest that cost divergence did not play a key role (e.g.,Wyplosz, 2013). ${ }^{2}$ At the same time, authors arguing from different theoretical perspectives but stressing the cost-competitiveness view have come to greatly different policy conclusions, namely austerity and internal devaluation on the one hand (e.g., European Commission, 2011), and exit or dissolution of the common currency on the other (e.g., Lapavitsas, 2015a, b). Second, those authors who are critical of the common currency to the point of recommending a dissolution are usually

2 In the case of Wyplosz, however, austerity seems even less viable than in the European Commission's case, since it is not obvious how austerity should eliminate structural current account imbalances, unless demand is to be kept depressed permanently. 
those who view cost divergences as the prime cause of imbalances. The main exception to this are the writers belonging to the modern monetary theory (MMT) strand of PK, who will be discussed below.

Table 4 Explanations of current account imbalances and policy recommendations

\begin{tabular}{|c|c|c|c|}
\hline & $\begin{array}{l}\text { Inflationary } \\
\text { adjustment in centre } \\
\text { countries: higher } \\
\text { wages and fiscal } \\
\text { expansion }\end{array}$ & $\begin{array}{l}\text { Euro-exit for deficit } \\
\text { countries or a } \\
\text { dissolution of the Euro }\end{array}$ & $\begin{array}{l}\text { Internal devaluation } \\
\text { and fiscal austerity in } \\
\text { deficit countries }\end{array}$ \\
\hline $\begin{array}{l}\text { Costs as prime } \\
\text { determinant of current } \\
\text { account imbalances; } \\
\text { little role for demand }\end{array}$ & $\begin{array}{l}\text { Priewe (2011) } \\
\text { Mazier and Petit (2013) }\end{array}$ & $\begin{array}{l}\text { Flassbeck and } \\
\text { Lapavitsas (2013) } \\
\text { Lapavitsas }(2015 a, b) \\
\text { Johnston et al. (2013) }\end{array}$ & $\begin{array}{l}\text { European Commission } \\
\text { (2011) } \\
\text { Sinn and Valentinyi } \\
(2013)\end{array}$ \\
\hline $\begin{array}{l}\text { Costs and demand as } \\
\text { important determinants } \\
\text { of current account } \\
\text { imbalances }\end{array}$ & $\begin{array}{l}\text { Stockhammer and } \\
\text { Sotiropoulos (2014) } \\
\text { Stockhammer (2016b) }\end{array}$ & & \\
\hline $\begin{array}{l}\text { Current account } \\
\text { imbalances driven by } \\
\text { demand developments, } \\
\text { not costs }\end{array}$ & $\begin{array}{l}\text { Storm and Naastepad } \\
\text { (2015a) }\end{array}$ & & $\begin{array}{l}\text { Diaz Sanchez andVa- } \\
\text { roudakis (2013) } \\
\text { GabrischandStaehr } \\
\text { (2014) } \\
\text { Wyplosz (2013) }\end{array}$ \\
\hline
\end{tabular}

Regarding the outcome of the debate on the importance of cost-competitiveness, the empirical evidence remains inconclusive and the estimates by different authors are difficult to compare. However, authors arguing against the price-competitiveness view have pointed out some important limitations particularly of aggregate ULC as a proxy for competitiveness. They have stressed the non-price dimensions of competitiveness and the importance of different trade-patterns. As such, it appears likely that if this debate is to be resolved, further examination of less aggregated data will be an important area of research.

While, as we have seen, PK writers can be found on both sides of the debate, there exists common ground among the PK participants of this debate on the importance of credit-led booms in driving trade imbalances as well as on the proposition that changes in the wage share, regardless of whether or not they have a direct impact on the current account through cost-competitiveness, are an important factor in driving changes in ef- 
fective demand and thus exert income effects on the trade balance since wages are not only a cost, but also a source of expenditure. This dimension is largely ignored in mainstream treatments of the problem. For PKs skeptical of the role of labour costs, policy prescriptions include the necessity of industrial policies to lead to a convergence of productive structures, financial regulation, and a correction of the obvious problems with the monetary and fiscal policy regimes. These recommendations are, by and large, shared by those post-Keynesians who do admit a role for costs. PostKeynesians on both sides of the debate generally tend to favour a reform rather than a dissolution of the Eurozone and are united in their rejection of the neoliberal EMU policy regime. One of the reasons for this is that in general (exceptions include e.g. Cesaratto, 2015), and in contrast to, for instance, the views of Flassbeck and Lapavitsas (2013) current account imbalances are not viewed as the central element to explaining the Euro crisis. In principle, a financial crisis could have arisen in Europe even in the absence of large trade imbalances - though in practice these were one important reason for increasing debt levels in peripheral economies - and the key to understanding why the financial crisis turned into a sovereign debt crisis lies in the restrictive monetary and fiscal policy regime.

The key point of this discussion is that contrary to the claim made by Baldwin and Giavazzi (eds., 2015), there is no consensus narrative on the Eurozone crisis. Indeed, there is not even consensus on what caused the current account imbalances preceding it, and neither on whether these are central to an explanation of the crisis. Baldwin and Giavazzi claim that they are, but we shall argue next that the flawed EMU policy architecture is far more important and holds the key to understanding the sovereign debt crisis.

\section{The crisis and the EU policy regime}

In the USA, the global financial crisis was countered by moderate countercyclical fiscal policy and by aggressive unconventional monetary policy (or quantitative easing), resulting in a weak recovery. Economic policy in Europe was less anti-cyclical. While countries adopted stimulus packages in 2008/09, from 2010 fiscal policy turned to austerity and, worse, it became most restrictive in the peripheral countries that were hardest hit by the crisis due to the large debt overhangs existing there. Stockhammer et 
al. (2016) use estimates of regime-dependent fiscal multipliers to calculate the demand effects of fiscal policy since the beginning of the crisis for several European countries. They find that the switch to fiscal austerity can explain a large portion of the deep downturns these countries have been experiencing during the sovereign debt crisis. By contrast, the neutral or mildly expansionary fiscal stances of core or non-euro economies such as Germany or the US can contribute to an explanation of the recoveries in these countries. Monetary policy in the EU tried to avoid quantitative easing as long as it could, but as the Euro crisis deepened, the ECB did expand its balance sheet. However, this strategy so far does not seem to be sufficient to stimulate growth, underscoring the importance and primacy of fiscal policy particularly during deep downturns. Given the different growth models and differences in economic policy, the crisis led to sharply different performances across Europe: a fragile recovery in the north and a depression in the southern European countries.

Nevertheless, the EU's policy package has not changed direction, but becomes, as of today, more rigid and doctrinaire. The Treaty for Stability, Coordination and Governance in the Economic and Monetary Union (TSCG) has tightened the grip on fiscal policy (Grahl, 2012). Constitutional debt breaks are to be introduced in the Euro member states; there will be an automatic obligation to austerity if public debt exceeds the $60 \%$ target and the European Commission will be involved in the national budget process (the European Semester). The recent five Presidents' report (Juncker, 2015a) reaffirms these commitments. The one area where there has been a change in direction is with respect to the no bail-out clause. The EU has, belatedly, set up a collective fund for member states that have lost access to market finance (EFSF, EMF). This fund gives loans to the countries that are misleadingly referred to as 'rescue packages' and imposes conditionality that is similar in spirit (if not as far reaching) to IMF adjustment programmes. The ECB has also found (overall insufficient) ways to circumvent its statute in practice, but there is no indication that a formal change of the ECB's role is being contemplated.

The policy response to the Euro crisis hence very much reflects the stance of the European institutions on the debate examined in the previous section. If one views the crisis primarily as an outcome of fiscal profligacy and divergences in (price) competitiveness, austerity both in terms of government spending and in terms of wage cuts is the obvious response 
from a mainstream perspective. Parts of the mainstream economics profession have shifted their views on fiscal policy in the wake of the global financial crisis (Blanchard; Leigh, 2013), and advocates of countercyclical fiscal policy, who may be termed mainstream Keynesians, have gained increasing prominence with their analyses of fiscal policy responses to the global financial crisis in general and the euro crisis in particular (e.g., Krugman, 2012; de Grauwe; Ji, 2013). EU policy, however, still reflects the orthodoxy prevailing prior to 2008 according to which deficit spending is inherently ineffective and austerity can in fact produce growth. This latter view, the idea of 'expansionary fiscal consolidation' (Giavazzi; Pagano, 1990), enjoyed its heyday prior to the crisis but has proved remarkably long-lived (Alesina; Ardagna, 2009) despite being based on only a handful of questionable observations (Chowdhury; Islam, 2012). Yet even on its own terms, the argument cannot be applied to the Eurozone periphery since the preconditions for an expansionary consolidation are most definitely not fulfilled in these economies (Bi et al., 2012). ${ }^{3}$ Nevertheless, an alleviation of fiscal austerity remains a taboo in Brussels and Berlin. Similarly, wages continue to be viewed solely as a cost factor with their role in demand formation, which is the theoretical foundation of the concept of wage-led growth, being ignored. This leads to the inevitable conclusion that only wage reductions can bring an increase in employment. That view is borne out in the single minded focus the European institutions put on competitiveness in terms of wage costs, with the planned 'National Competitiveness Authorities' (Juncker, 2015a) being aimed at convergence to the 'best' performances, i.e., the lowest prevailing standards in terms of wage settlements.

The PK opinion on internal devaluation, based on the conclusions drawn from empirical research on demand regimes, has already been outlined above and is shared universally within the school. Given the empirical finding that the Eurozone as a whole is in a wage-led regime, generalised downward pressure on wages is likely to have the opposite effect to that intended by EU policy. As regards fiscal policy, the crisis has illustrated

3 These preconditions include that a consolidation must be expected to be based on tax increases but actually turn out to be spending-based, and that expansionary monetary policy can compensate for any contractionary effects. Since consolidations in the European periphery were from the outset planned to be based largely on spending cuts and since monetary policy is already highly expansionary without great effects, an expansionary consolidation seems highly unlikely even on the theory's own terms. 
the strong interdependence of the government sector and the financial system. Mainstream economics, but also Marxist Political Economy, regard money as emerging from private transactions. By contrast, PK theory and economic sociology stress that debt relations and in particular government debt and the ability of governments to collect taxes in their own currency are the foundation of money (Goodhart, 1998; Graeber, 2011, chapters 2 and 3). Ingham (2004) emphasizes the state origin of money, but highlights that the social mode of production of credit money is through private banks. Money, thus, has sovereign power as a constituent element, but private institutions are critically involved. This balance between the state and the private sector in the creation of money has been upset by the EMU, which separated fiscal and monetary spaces and insulated the European Central Bank from national governments. Central bank independence was strengthened and the ECB was forbidden to fund governments directly. By design, it was meant to be a lender of last resort for the private sector only.

Marxist economists in practice, despite their differing and often somewhat eclectic views on the nature of money, tend to agree with the PK case for fiscal policy effectiveness (Lapavitsas, 2015b) but also doubt its ability to offset tendencies for capitalist crises in the long run (Kotz, 2010). This is reflected in their assessment of the Euro crisis outlined above, in which ULC and trade imbalances are central, with less emphasis on the role of the EU fiscal and monetary policy regime. Marxists also tend to assume that economies are profit-led, meaning that there is no clear-cut economic case against internal devaluation from this perspective. While wage-cuts may be viewed as socially undesirable, it is not clear why they should not eventually result in a recovery. In this case, the only alternative to internal devaluation would be an exit from the single currency since devaluation could then take place through an independent currency, lessening the burden on workers.

The crisis is, in our view, ultimately due to the neoliberal economic policy regime that has forced countries in recession to impose austerity and has seriously damaged the ability of nation states to counter an economic crisis, by making central bank backing conditional on fiscal policy conditionality. The restrictions on fiscal policy directly impede governments on the expenditure side. In particular, it has forced those countries most desperately in need of expansionary fiscal policies to pursue austerity. The loss of monetary sovereignty means that countries cannot set interest rates 
and, more importantly in times of sovereign debt crisis, they do not have the lender of last resort facility to support the government. The public finances of Eurozone countries are hence subject to financial market pressures and speculation by the very same institutions which had earlier been bailed out. All these dysfunctional features of the European economic regime are not an accident, but a part of the neoliberal agenda of subjecting states to market discipline.

While our story is a bleak one, given the dominance of neoliberalism in European policy making, it also suggests a series of reforms that could overcome the crisis without the need for a breakup. Policies, both related to wage costs and productive structures, to eliminate current account imbalances in an inflationary rather than a deflationary fashion would be desirable, but it is reform of the fiscal and monetary policy regime that would strike at the heart of the problem. While the need for a reform of the fiscal and monetary policy framework of the Eurozone seems to be gaining increasing acceptance within the economics profession, the field is certainly far from having reached a consensus position both on the need for and the design of such a reform. Additionally, there is little evidence that European institutions (or the German finance ministry) have any desire to rethink its policy framework. The next section will, by way of conclusion, briefly outline the general features of a PK reform of the Eurozone and contrast it with ideas closer to the mainstream.

\section{A post-Keynesian policy package for the Eurozone}

The common currency turned what would otherwise have been an exchange rate crisis into a sovereign debt crisis. The separation of monetary and fiscal space fatally weakened the ability to counteract the crisis. The set of rules effectively leaves few policy variables at the states' availability and encourages a wage policy that aims at competitive devaluation. Wages, for better or worse, are left as the adjusting variable. At the root of the crisis is a build-up of debt, fueled by financialisation and, in this particular case, manifesting itself in demand booms underlying the debt-driven and export-driven variants of neoliberal growth models and reflecting current account imbalances. However, the key to explaining the crisis does not lie in explaining these imbalances, but rather the flaws of the EMU policy 
architecture which differentiate the Eurozone from economies such as the UK and the USA which similarly experienced debt-fueled booms and financial crises, but did not suffer a sovereign debt crisis since they possess less dysfunctional fiscal and monetary policy regimes.

The financial crisis escalated in Europe because fiscal policy and monetary policy were less anti-cyclical than in Anglo-Saxon countries. The crisis turned into a sovereign debt crisis in southern Europe because of the separation of monetary and fiscal spaces, or in other words, the treatyconsistent refusal of the ECB to back the governments of the EU member states. This is an explanation on which, we believe, most PKs, regardless of their views on the importance of ULC in determining trade balances can agree. PKs from the MMT strand, in line with their theoretical perspective which stresses the importance of monetary sovereignty also put this aspect at the centre of their discussions of the Eurozone, arguing that the loss of monetary sovereignty of Eurozone member states in combination with a non-existent European fiscal policy and a restrictive ECB mandate account for the severity of the crisis. However, in contrast to our policy recommendations, followers of MMT tend to be more favourable toward and relaxed about a potential break-up of the Eurozone or the exit of individual members (Wray, 2011) than European PKs who generally favour a reformed Eurozone along the lines described below.

Europe faces several challenges: it has to stimulate demand, address high private and public debt and ideally also eliminate trade imbalances. A strategy to eliminate trade imbalances should combine insights from both post-Keynesian camps on the ULC debate. Wage policy should not aim at wage flexibility and internal devaluation as recommended by the EU institutions and mainstream advocates of the cost-competitiveness view, but at an equitable income distribution and, especially in those countries with weak domestic demand (such as Germany), inflationary growth and domestic demand formation. This requires a strengthening of collective bargaining structures and ought to be complemented by a European system of national minimum wages (Schulten; Watt, 2007). The macroeconomic aim of European wage coordination ought to be higher wage growth in the trade surplus countries which would help prevent imbalances both by stimulating demand in surplus countries and, to the extent that imbalances are caused by this factor, by bringing relative costs in line. At the same time, deficit countries require large amounts of productive investment and 
an industrial policy aimed at the upgrading of productive structures to eliminate structural trade imbalances which cannot be eliminated by any amount of internal devaluation in deficit countries or internal revaluation in surplus countries. Of course, these measures, especially those aimed at technological upgrading, would only be effective in the longer run. Some PKs hold that the elimination of trade imbalances and their underlying causes (which by them are seen to be chiefly divergences in ULC) are imperative for solving the difficulties faced by the Eurozone (Cesaratto, 2015). In some cases, this appears to lead to the conclusion that an exit from the Euro, followed by currency devaluations for the deficit countries may be the best option (Vernengo, 2015). Others have argued that the flawed monetary and fiscal policy setup, especially the lack of monetary sovereignty of member states (Lavoie, 2015) and the power of the financial sector (Wray, 2012), are the major reason for the crisis, leading to a lengthy discussion of whether or not the Euro crisis should be interpreted as a balance of payments crisis. Without delving too deeply into this debate, we would contend that while it is true that the current crisis resembles a balance of payments crisis in many respects, this does not imply that the Eurozone's problems could be solved through ensuring that no current account imbalances emerge in the future. The flawed fiscal and monetary policy regimes would still leave the Eurozone exceptionally vulnerable to financial crises even in the absence of trade imbalances. Thus, as we have argued above, the most pressing issue is a reform of the fiscal and monetary policy regimes and regulation of the financial sector.

Thus, a PK policy package must free fiscal policy from the shackles of the present regime. Fiscal policy has to be used to ensure that aggregate demand is at a level to ensure full employment. This implies a strong counter-cyclical component. Part of this can be delivered by automatic stabilisers but a substantial part must be discretionary policy. States need to be able to react if their economy is facing a recession or high unemployment. In the current environment, this means that the southern European countries should see large increases in government spending, both to raise employment and to undertake productive investment aimed at technological upgrading rather than fiscal austerity aimed at permanently depressing effective demand. Ideally, these expenditures would come out of a European budget, but the current stance of the European institutions provides little hope for anything going beyond a restricted system of auto- 
matic stabilisers at the European level (Juncker, 2015a). To guarantee that financial crises never again escalate into sovereign debt crises, the ECB's mandate must be reformed to ensure monetary backing for fiscal policies, regardless of whether they take place at the national or European level.

Lastly, the financial sector needs to be restructured and contracted. An inflationary environment would facilitate reducing private and public debt levels, but debt restructuring will in some cases be necessary to make debt manageable. To counteract the regressive distributional effects of bank rescues, a substantial wealth tax would have to be introduced. Bailedout financial institutions would be put under public control to ensure change in management practices. Monetary policy should be reoriented away from single-minded inflation targeting, which was long advocated by the mainstream yet is based on questionable evidence (Bibow, 2010), and instead lean against asset price bubbles using a richer set of macroprudential instruments, e.g., asset-specific reserve requirements to control destabilizing credit growth and capital flows. Through the measures outlined above, the common currency could be preserved and placed on a sustainable foundation. It remains to be seen whether the PK analyzes its policy recommendations as presented, which differ significantly from the alleged consensus on the Eurozone crisis presented by Baldwin and Giavazzi (2015), will manage to have any impact on the future direction of the EMU.

\section{References}

ALESINA, A.; ARDAGNA, S. Large changes in Fiscal Policy: Taxes versus spending. NBER Working Paper No. 15438, 2009.

ARGHYROU, M. G.; CHORTAREAS, G. Real exchange rate and current account imbalances in the Euro area. Review of International Economics, v.9, n.5, p. 747-764, 2008.

ATKINSON, A.; PIKETTY, T.; SAEZ, E. Top incomes in the long run of history. Journal of Economic Literature, v.49, n.1, p. 3-71, 2011.

BALDWIN, R.; GIAVAZZI, F. (Eds.). The Eurozone Crisis - A consensus view of the causes and a few possible solutions. London: CEPR Press, 2015.

BELKE, A.; DREGER, C. Current account imbalances in the Euro area: catching up or competitiveness? Deutsches Institut für Wirtschaftsforschung Discussion paper No. 1106, 2011.

BELLOFIORE, R.; GARIBALDO, F; HALEVI, J. The Global Crisis and the Crisis of European Neomercantilism. Socialist Register 2011: The crisis this time. London: Merlin, 2011, p.120-46. 
BERGER H.; NITSCH, V. The Euro's effect on trade imbalances. IMF Working Paper No. 10/226, 2010.

BI, H.; LEEPER, E.; LEITH, C. Uncertain Fiscal Consolidations. The Economic Journal, v.123, n.566, p. F31-F63, 2012.

BIBOW, J. A Post Keynesian Perspective on the rise of Central Bank Independence: A dubious success story in Monetary Economics. Levy Economics Institute Working Paper No. 625, 2010.

BLANCHARD, O.; LEIGH D. Growth forecast errors and fiscal multipliers. IMF Working Pa$\operatorname{per}$ No. 13/1, 2013.

BRENNER, N.; PECK, J.; THEODORE, N. Variegated neoliberalization: geographies, modalities, pathways. Global Networks, v.10, n.2, p. 182-222, 2010.

CESARATTO, S. Balance of Payments or Monetary Sovereignty? In search of the EMU's original sin, International Journal of Political Economy, v.44, n.2, p. 142-156, 2015.

CHARLES, S. Teaching Minsky's financial instability hypothesis: a manageable suggestion. Journal of Post Keynesian Economics, v.31, n.1, p.125-38, 2008.

CHOWDHURY, A.; ISLAM, I. The debate on expansionary fiscal consolidation: How robust is the evidence? The Economic and Labour Relations Review, v.23, n.3, p. 13-38, 2012.

DARDOT, P.; LAVAL, C. The new way of the world: On neoliberal society. London: Verso, 2013.

DE GRAUWE, P.; JI, Y. Panic-driven austerity in the Eurozone and its implications, VoxEU. org, 21 $1^{\text {st }}$ February, 2013. Available online at: <http://www.voxeu.org/article/panic-drivenausterity-eurozone-and-its-implications $>$.

DIAZ SANCHEZ, J L.; VAROUDAKIS, A. Growth and competitiveness as factors of Eurozone external imbalances: evidence and policy implications. World Bank Policy Research Working Paper No. 6732, 2013.

DRAGHI, M. Competitiveness of the euro area and within the euro area. Speech at the colloquium "Les défis de la compétitivité", 2012.

DUMÉNIL, G.; LÉVY. D. Capital Resurgent. Roots of the neoliberal revolution. Cambridge, MA: Harvard University Press, 2004.

EUROPEAN COMMISSION. Quarterly Report on the Euro Area, v.10, n.3. October, 2011. Available online at: <http://ec.europa.eu/economy_finance/publications/qr_euro_area/2011/ qrea3_en.htm>.

FLASSBECK, H.; LAPAVITSAS, C. The systemic crisis of the Euro - True causes and effective therapies. Study of the Rosa Luxemburg Foundation, 2013.

FOUCAULT, M. The Birth of Biopolitics: Lectures at the College de France, 1978-1979. Houndsmills: Palgrave MacMillan, 2008.

FOURCADE-GOURINCHAS, M.; BABB, S. The rebirth of the liberal creed: paths to Neoliberalism in four countries. American Journal of Sociology, v.108, n.3, p. 533-79, 2002.

GABRISCH, H.; STAEHR, K. The Euro Plus Pact - Cost Competitiveness and External Capital Flows in the EU Countries, ECB Working Paper No. 1650, 2014.

GABOR, D.; BAN, C. Banking on bonds: the new links between states and markets. Journal of Common Market Studies, forthcoming, 2016. 
GIAVAZZI, F.; PAGANO, M. Can severe fiscal contractions be expansionary? Tales of two small European countries. NBER Working Paper No. 3372, 1990.

GLYN, A. Capitalism unleashed: Finance, globalization and welfare. Oxford University Press, 2006.

GOODHART, C. The two concepts of money: implications for the analysis of optimal currency areas. European Journal of Political Economy, v.14, n.3, p.407-432, 1998.

GRAEBER, D. Debt. The first 5000 Years. New York: Melville House, 2011.

GRAHL, J. Global Finance and Social Europe. Aldershot: Edward Elgar, 2009.

GRAHL, J. The First European Semester: an incoherent strategy. Paper presented at the PERG workshop Europe in Crisis, April 2012, Kingston University, 2012.

HALL, P. Varieties of Capitalism and the Euro Crisis. West European Politics, v.37, n.6, p. 12231243, 2014.

HARVEY, D. A Short History of Neoliberalism Oxford: Oxford University Press, 2005.

HEIN, E. The Macroeconomics of Finance-Dominated Capitalism - And Its Crisis. Cheltenham: Edward Elgar, 2012.

HEIN, E. The crisis of finance-dominated capitalism in the euro area, deficiencies in the economic policy architecture, and deflationary stagnation policies. Journal of Post Keynesian Economics, v.36, n.2, p.325-354, 2013.

HEIN, E.; VOGEL, L. Distribution and growth reconsidered - empirical results for six OECD countries. Cambridge Journal of Economics, v.32, p.479-511, 2008.

INGHAM, G. The Nature of Money. Cambridge: Polity Press, 2004.

JOHNSTON, A.; HANCKÉ, B.; PANT, S. Comparative Institutional Advantage in the European Debt Crisis. LEQS Paper No. 66, 2013.

JUNCKER, J. Completing Europe's Economic and Monetary Union, 22 nd June, 2015a.

JUNCKER, J. Preparing for Next Steps on Better Economic Governance in the Euro Area. Analytical Note, Informal European Council, $12^{\text {th }}$ February, $2015 \mathrm{~b}$.

KOTZ, D. The Final Conflict: What Can Cause a System-Threatening Crisis of Capitalism? Science \& Society, v.74, n.3, p. 362-379, 2010.

KRUGMAN, P. End this Depression now! New York, NY: W. W. Norton \& Company, 2012.

LAPAVITSAS, C. Greece: Phase Two, Interview, Jacobin Magazine Online, 12 ${ }^{\text {th }}$ March, 2015a. Available online at: <http://www.jacobinmag.com/2015/03/lapavitsas-varoufakis-grexitsyriza/>.

LAPAVITSAS, C. The case for Grexit, Verso Books Blog, $5^{\text {th }}$ August, 2015b. Available online at: $<$ http://www.versobooks.com/blogs/2163-costas-lapavitsas-the-case-for-grexit>.

LAVOIE, M.; STOCKHAMMER, E. Wage-led growth: concept, theories and policies. In: LAVOIE, M.; STOCKHAMMER, E. (Eds.). Wage-led growth. An equitable strategy for economic recovery. London: Palgrave Macmillan, p. 13-39, 2013.

LAVOIE, M. Post-Keynesian Economics - New Foundations. Cheltenham: Edward Elgar, 2014.

LAVOIE, M. The Eurozone: Similarities to and differences from Keynes's Plan. International Journal of Political Economy, v.44, n.1, p. 3-17, 2015. 
MAZIER, J.; PETIT, P. In search of sustainable paths for the Eurozone in the troubled post2008 world. Cambridge Journal of Economics, v.37, n.3, p. 513-532, 2013.

MCCLOSKEY, D.; ZILIAK, S. The standard error of regressions. Journal of Economic Literature, v.34, n.1, p. 97-114, 1996.

MINSKY, H. P. Stabilizing an unstable economy. New Haven: Yale University Press, 1986.

MIROWKSI, P.; PLEHWE, D. The Road from Mont Pelerin. Cambridge, MA: Harvard University Press, 2009.

ONARAN, Ö.; GALANIS, G. Income distribution and growth: a global model. Environment and Planning, v.A46, n.10, p. 2489-2513, 2014.

PRIEWE, J. European imbalances and the crisis of the European Monetary Union. In: HERR, H.; NIECHOJ, T.; THOMASBERGER, C.; TRUGER, A.; VAN TREECK, T. (Eds.). From Crisis to Growth? The challenge of debt and imbalances. Marburg: Metropolis, p. 331-360, 2011.

SAMARINA, A.; BEZEMER, D. Capital Flows and Financial Intermediation: is EMU different?, SOM Research Report No. 14021-GEM, 2014.

SCHULTEN, T.; WATT, A. European minimum wage policy -a concrete project for a social Europe. ETUI European Economic and Employment Policy Brief No 2, 2007.

SINN, H.; VALENTINYI, A. European Imbalances, VoxEU.org, 9 $9^{\text {th }}$ March, 2013. Available online at: <http://www.voxeu.org/article/european-imbalances>.

SINN, H. Austerity, growth and inflation: Remarks on the Eurozone's unresolved competitiveness problem. The World Economy, v.37, n.1, p. 1-13, 2014a.

SINN, H. The Euro Trap - On bursting bubbles, budgets, and beliefs. Oxford: Oxford University Press, $2014 b$.

STOCKHAMMER, E.; ONARAN, Ö.; EDERER, S. Functional income distribution and aggregate demand in the Euro area. Cambridge Journal of Economics, v.33, n.1, p. 139-159, 2009.

STOCKHAMMER, E.; SOTIROPOULOS, D. Rebalancing the Euro area: the costs of internal devaluation. Review of Political Economy, v.26, n.2, p. 210-33, 2014.

STOCKHAMMER, E.; DURAND, C.; LIST, L. European Growth Models and Working Class Restructuring before the Crisis. Environment and Planning A, v.48, n.9, p. 1804-1828, 2016.

STOCKHAMMER, E.; WILDAUER, R. Debt-driven growth? Wealth, distribution and demand in OECD countries. Cambridge Journal of Economics, forthcoming, 2016.

STOCKHAMMER, E. Peripheral Europe's debt and German wages. International Journal for Public Policy, v.7, n.1-3, p. 83-96, 2011.

STOCKHAMMER, E. Financialization, income distribution and the crisis. Investigación Económica, v.71, n.279, p. 39-70, 2012.

STOCKHAMMER, E. Determinants of the wage share. A panel analysis of advanced and developing economies. British Journal of Industrial Relations, forthcoming, $2016 \mathrm{a}$.

STOCKHAMMER, E. Neoliberal growth models, monetary union and the Euro Crisis. A post-Keynesian perspective. New Political Economy, v.21, n.4, p. 365-79, 2016 b.

STORM, S.; NAASTEPAD, C.W.M. Europe's Hunger Games: Income distribution, cost competitiveness and crisis. Cambridge Journal of Economics, v.39, n.3, p. 959-986, $2015 \mathrm{a}$. 
STORM, S.; NAASTEPAD, C. W. M. Myths, Mix-ups and Mishandlings: What caused the Eurozone Crisis? Institute for New Economic Thinking Annual Conference, Paris, $2015 \mathrm{~b}$. Available online at:<http://www.ineteconomics.org/uploads/papers/The-Eurozone-Crisis.pdf $>$.

STORM, S.; NAASTEPAD, C.W.M. NAIRU economics and the Eurozone crisis. International Review of Applied Economics, v.29, n.6, p. 843-877, 2015c.

THOMASBERGER, C. Europäische Geldpolitikzwischen Marktzwängen und neueninstitutionellen Regelungen. Zurpolitischen Ökonomie der europäischen Währungsintegration. Marburg: Metropolis, 1995.

VERNENGO, M. More on currency crises and the euro crisis. Naked Keynesianism, $28^{\text {th }}$ May, 2015. Available online at: <http://www.nakedkeynesianism.blogspot.co.uk/2015/05/ more-on-currency-crises-and-euro-crisis.html>.

WRAY, L. R. Warren Mosler's Big Fat Greek MMT Exit Strategy. Econo Monitor, $17^{\text {th }}$ November, 2011. Available online at:<http://www.economonitor.com/lrwray/2011/11/17/warren-moslers-big-fat-greek-mmt-exit-strategy/>

WRAY, L. R. Imbalances? What Imbalances? A Dissenting View. Levy Economics Institute Working Paper No. 704, 2012.

WYPLOSZ, C. Eurozone Crisis: It's about demand, not competitiveness. Draft Working Paper, 2013. Available online at: <http://www.tcd.ie/Economics/assets/pdf/Not_competitiveness.pdf>.

ZHANG, L.; BEZEMER, D. A global house of debt effect? Mortgages and post-crisis recessions in fifty economies. SOM Research Reports No. 15009, 2015.

\section{About the authors}

Engelbert Stockhammer - E.Stockhammer@kingston.ac.uk

Kingston University, London.

CollinConstantine-k1543752@kingston.ac.uk

Kingston University, London.

SeverinReissl-severin.reissl@gmail.com

Kingston University, London.

Section 2 builds closely on Stockhammer (2016b).We are grateful to Ewa Karwowski, an anonymous referee and the editor for helpful comments. The usual disclaimers apply.

\section{About the article}

Submission received on March 16, 2016. Approved for publication on April 27, 2016. 